\title{
Pengaruh Motivasi terhadap Hasil Belajar Pendidikan Agama Islam Siswa di Sekolah Menengah Atas
}

\author{
Meli Sopiani' ${ }^{1}$, Wirdati ${ }^{2}$ \\ melisopiani@07@gmail.com,wirdati@fis.unp.ac.id \\ Universitas Negeri Padang1,2
}

\begin{tabular}{l}
\hline ARTICLE INFO \\
\hline Article history: \\
Received, 10 October 2021 \\
Revised, 09 November \\
2021 \\
Accepted, 30 November \\
2021 \\
\hline
\end{tabular}

\section{Keywords:}

Pengaruh, Motivasi Belajar, Hasil Belajar, Pendidikan Agama Islam.

\section{Clonflict of Interest:}

None

\section{Funding:}

None

\begin{abstract}
Penelitian ini dilakukan untuk mengetahui pengaruh motivasi belajar terhadap hasil belajar siswa pada mata pelajaran Pendidikan Agama Islam di SMA Negeri 1 Tanjung Mutiara Kabupaten Agam. Metode penelitian yang digunakan adalah metode kuantitatif asosiatif dengan teknik penganalisisan data deskriptif kuantitatif, uji prasyarat analisis menggunakan uji normalitas dan uji linearitas, untuk uji hipotesis dilakukan dengan analisis regresi linier sederhana dan untuk sampel dilakukan dengan Teknik purposive sampling. Hasil penelitian ini menunjukkan bahwa motivasi belajar siswa dalam kategori tinggi, sedangkan hasil belajar siswa pada mata pelajaran Pendidikan Agama Islam tergolong dalam kategori sedang. Berdasarkan hasil perhitungan yang telah dilakukan diperoleh koefisien determinasi sebesar 0,615 (61,5\%) artinya variabel indenpenden (motivasi belajar) memberikan pengaruh yang kuat terhadap variabel dependen (hasil belajar) yaitu sebesar 61,5\% sedangkan $38,5 \%$ dipengaruhi oleh faktor lainnya. Artinya terdapat pengaruh yang signifikan antara motivasi belajar dengan hasil belajar siswa. Dengan demikian diharapkan guru Pendidikan Agama Islam di Sekolah Menengah Atas harus selalu berusaha meningkatkan motivasi belajar siswa, guru dapat membantu siswa dalam meningkatkan motivasi pada diri siswa agar menjadi lebih baik sehingga siswa memiliki motivasi belajar yang tinggi, dan pencapaian dalam hasil belajarnya menjadi optimal.
\end{abstract}

Corresponding Author: Meli Sopiani, Department Islamic Education Faculty of Social Science Universitas Negeri Padang, Indonesia, Email: melisopiani07@gmail.com Phone: +62822-8494-7980

\begin{tabular}{l|cc|l}
\hline & CC) & (9) & Copyright@2021, Author(s) \\
\hline
\end{tabular}

\section{Pendahuluan}

Pendidikan adalah seperangkat strategi yang digunakan untuk membantu orang mempelajari pengetahuan, pemahaman, dan cara berperilaku yang disesuaikan dengan kebutuhan spesifik mereka. Pendidikan juga merupakan jenis kegiatan kelembagaan yang digunakan untuk membantu masyarakat meningkatkan pengetahuan, sikap, dan kebiasaannya (Syah, 2004). Dalam suatu lembaga pendidikan, hasil belajar merupakan indikator yang penting untuk mengukur keberhasilan proses belajar mengajar. Hasil belajar 
merupakan prestasi yang diperoleh seorang siswa sebagai cerminan dari pencapaian kompetensi belajar siswa tersebut (Andriani \& Rasto, 2019). Hasil belajar juga merupakan laporan pencapaian mengenai apa yang sudah diperoleh oleh siswa. Tujuan hasil belajar adalah untuk mengetahui sejauh mana siswa dapat menguasai pelajaran setelah mengikuti kegiatan pembelajaran atau tingkat keberhasilan yang dicapai seorang siswa setelah mengikuti proses belajar mengajar, yang diukur dengan menggunakan angka, huruf, atau symbol yang disepakati oleh penyelenggara pendidikan. Proses belajar itu dipengaruhi oleh dua faktor yaitu faktor internal dan faktor eksternal. Faktor internal adalah faktor yang berasal dari dalam diri individu yang belajar yaitu intelegensi, emosi, bakat, motivasi dan perhatian. Sedangkan faktor eksternal adalah segala sesuatu yang berada diluar diri individu yang dapat mempengaruhi proses belajarnya (Karwono \& Mularsih, 2018).

Motivasi belajar siswa merupakan salah satu faktor yang dapat mempengaruhi keberhasilan belajar siswa, karena apabila siswa berpedoman pada dimensi-dimensi motivasi maka akan menimbulkan hasil belajar yang sangat baik bagi siswa (Andriani \& Rasto, 2019). Disisi lain dipahami bahwa motivasi sangat diperlukan dalam meningkatkan hasil belajar siswa karena motivasi dapat menjadi penentu berhasil atau tidaknya kegiatan belajar siswa (Biatun, 2020). Oleh sebab itu motivasi belajar merupakan salah satu faktor penentu hasil belajar siswa. Dapat dipahami bahwa salah satu faktor yang mempengaruhi hasil belajar dari siswa yaitu motivasi karena motivasi yang ada pada diri seseorang dapat mendorong dirinya berusaha lebih giat sehingga memperoleh hasil yang lebih besar.

Berdasarkan observasi lapangan di SMA Negeri 1 Tanjung Mutiara Kabupaten Agam terlihat adanya sebagian dari siswa sudah memiliki motivasi yang tinggi dalam belajarnya Hal itu terlihat dari kesungguhan mereka dalam belajar. Namun sebagian siswa masih terlihat kurang memiliki motivasi belajar dalam pelajaran Pendidikan Agama Islam. Hal itu terlihat pada proses pembelajaran, banyak siswa yang kurang memperhatikan materi yang diberikan oleh guru, adanya siswa yang sering absen, tidak mengerjakan PR, datang terlambat, sikap yang kurang baik, bermalas-malasan dalam belajar PAI, sering bermain game sehingga berdampak terhadap hasil belajarnya. Motivasi yang kurang dalam diri siswa tentu akan meyebabkan hasil belajar yang diperoleh oleh siswa tidak sesuai dengan harapan. Hal ini terlihat dari hasil belajar yang diperoleh siswa pada Ujian Tengah Semester, yang mana sebagian besar dari siswa belum bisa memenuhi Kriteria Ketuntasan Minimal (KKM) pada mata pelajaran Pendidikan Agama Islam.

\section{Tinjauan Pustaka}

Pendidikan Agama Islam adalah usaha yang disengaja yang dilakukan oleh pendidik untuk mempersiapkan peserta didik agar percaya, memahami, dan mengamalkan ajaran Islam melalui kegiatan bimbingan, pengajaran, atau pelatihan yang telah ditentukan untuk memenuhi tujuan yang telah ditetapkan (Titin, 2016). Sedangkan menurut Syafaat \& Sahrani (2008) Pendidikan Agama Islam yaitu usaha yang berupa pengajaran bimbingan dan asuhan terhadap anak agar kelak selesai pendidikannya dapat memahami, menghayati dan mengamalkan Agama Islam serta menjadikannya sebagai jalan kehidupan baik pribadi maupun kehidupan masyarakat. Dapat disimpulkan bahwa Pendidikan Agama Islam merupakan usaha sadar yang dilakukan oleh seorang pendidik dalam rangka mempersiapkan peserta didik untuk meyakini, memhami, dan mengamalkan ajaran islam melalui kegiatan bimbingan, pengajaran atau pelatihan yang telah ditentukan untuk mencapai tujuan yang telah ditetapkan.

Pendidikan Agama Islam di sekolah atau madrasah bertujuan untuk menumbuhkan serta meningkatkan keimanan melalui pemberian dan pemupukan pengetahuan, penghayatan, pengamalan serta pengalaman peserta didik tentang agama islam sehingga menjadi manusia yang terus berkembang dalam hal keimanan, ketakwaan, berbangsa dan bernegara, serta untuk dapat melanjutkan pada jenjang pendidikan yang lebih tinggi. Menurut Nazarudin (2007) Pendidikan Agama Islam di sekolah bertujuan untuk meningkatkan keimanan, 
pemahaman, penghayatan, dan pengalaman siswa terhadap ajaran Agama Islam sehingga menjadi manusia yang bertaqwa kepada Allah SWT.

Hasil belajar merupakan kumpulan pengalaman siswa yang mencakup ranah kognitif, emosional, dan psikomotorik (Rusman, 2018). Hasil belajar juga merupakan perubahanperubahan yang terjadi pada diri siswa, baik menyangkut aspek kognitif, afektif, dan psikomotor sebagai hasil dari kegiatan pembelajaran (Susanto, 2013). Hasil belajar adalah terjadinya perubahan tingkah laku dari yang awalnya tidak bisa menjadi bisa (Warti, 2018). Dapat disimpulkan bahwa hasil belajar dapat didefinisikan sebagai keterampilan yang diperoleh siswa setelah terlibat dalam kegiatan belajar. Karena pada dasarnya belajar itu sendiri merupakan suatu bentuk perubahan perilaku yang relatif menetap.

Keberhasilan siswa dalam mencapai hasil belajar yang baik dipengaruhi oleh beberapa faktor. Hasil belajar yang dicapai oleh peserta didik merupakan interaksi antara berbagai faktor yang mempengaruhi, baik faktor internal maupun eksternal (Rambe, 2018). Faktor internal merupakan faktor yang bersumber dari dalam diri peserta didik, yang mempengaruhi kemampuan belajarnya. Faktor internal ini meliputi kecerdasan, minat dan perhatian, motivasi belajar, ketekunan, sikap, kebiasaan belajar, serta kondisi fisik dan kesehatan. Sedangkan faktor ekstenal merupakan faktor yang berasal dari luar diri peserta didik yang mempengaruhi hasil belajar yaitu keluarga, sekolah, dan masyarakat. Hasil belajar merupakan suatu kemampuan yang diperoleh oleh siswa setelah melewati proses belajarnya. Menurut Mudjiono (2006) indikator dari hasil belajar diklasifikasikan menjadi tiga macam yaitu: aspek kognitif, aspek afektif, dan aspek psikomotor

Motivasi adalah daya dorong umum yang ada dalam diri siswa yang dapat menimbulkan kegiatan belajar dan menjamin berlangsungnya kegiatan belajar, sehingga memungkinkan siswa mencapai tujuan mata pelajaran yang diinginkan (Sardiman, 2012). Motivasi belajar juga merupakan keseluruhan daya penggerak yang berasal dalam diri siswa yang menimbulkan kegiatan belajar serta menjamin kelangsungan kegiatan belajar dan memberikan arah terhadap kegiatan belajar itu demi mencapai suatu tujuan (Munib, 2017). Harmalis (2019) memiliki pandangan serupa, yang menyatakan bahwa motivasi belajar merupakan suatu dorongan atau penggerak yang berasal dari dalam maupun dari luar diri peserta didik dalam melakukan aktifitas belajar agar mampu menguasai materi pelajaran yang dipelajarinya yang berkaitan dengan aspek afektif, kognitif, dan psikomotor. Jadi, berdasarkan penjelasan di atas, motivasi belajar adalah suatu daya penggerak yang ada dalam diri seseorang yang membangkitkan dan mengarahkan semangat untuk mau melakukan kegiatan dan kegiatan belajar guna mencapai tujuan yang diinginkan.

Dalam memaknai motivasi para ilmuan psikologis mempunyai pemikiran yang berbeda satu sama lainnya sesuai dengan bidang keilmuan yang mereka dalami serta sudut pandangnya. Menurut (Asnawi, 2007) adapun teori-teori tentang motivasi yaitu : 1). Teori hedinisme; 2). Teori instings; 3). Drive teori; 4). Teori motivasi insentif; 5). Teori Abraham maslow.

Motivasi terbagi menjadi dua macam yaitu: 1). Motivasi instrinsik mengacu pada motivasi yang muncul dan menjadi aktif tanpa memerlukan rangsangan dari luar karena individu sudah memiliki keinginan untuk bertindak (Sardiman,2011). Motivasi eksrtinsik diartikan sebagai motivasi yang timbul dan aktif sebagai akibat adanya rangsangan dari luar. Motivasi mempunyai fungsi yang sangat penting dalam belajar siswa, kerena motivasi akan menentukan intensitas usaha belajar yang dilakukan oleh siswa. Wahab (2016) menyatakan bahwa motivasi sangat berperan dalam proses belajar seseorang karena fungsi dari motivasi adalah: 1). Sebagai pendorong perbuatan; 2). Sebagai penggerak perbuatan; 3). Sebagai pengarah perbuatan.

Terdapat banyak faktor yang dapat mempengaruhi motivasi belajar pada diri siswa yaitu, faktor pengetahuan tentang kegunaan belajar, kebutuhan untuk belajar, kemampuan melakukan kegiatan pembelajaran, hasil belajar (Mudjiman, 2007). Siswa yang menganggap belajar sebagai suatu kebutuhan akan senantiasa terbiasa untuk menjadikan belajar sebagai kegiatan yang disenangi. 
Adapun bentuk motivasi yang dapat dimanfaatkan dalam rangka mengarahkan belajar peserta didik, yaitu: memberi angka, hadiah, kompetisi, memberikan evaluasi dan pujian. motivasi yang ada pada setiap orang itu memiliki ciri-ciri yaitu, adanya hasrat dan keinginan untuk berhasil, adanya dorongan dan kebutuhan dalam belajar, adanya harapan dan cita-cita masa depan, adanya penghargaan dalam belajar, adanya keinginan yang menarik dalam belajar, serta adanya lingkungan pembelajaran yang kondusif (Haq, 2018). Untuk mengetahui ada atau tidaknya motivasi belajar pada diri peserta didik, dapat dilihat dari beberapa indikator-indikator belajar peserta didik, diantaranya yaitu: kesungguhan untuk belajar, perasaan senang, perhatian dalam belajar, kerajinan belajar, dan kesadaran akan manfaat mata pelajaran (Djamarah, 2002).

\section{Metode}

Penelitian ini menggunakan metode penelitian kuantitatif dan jenis penelitian kuantitatif asosiatif. Data yang diperoleh berupa angka-angka yang bersumber dari sumber data yang diteliti. Teknis penganalisisan data yang digunakan dalam penelitian ini adalah deskriptif dan analisis regresi sederhana yang bertujuan untuk melihat pengaruh motivasi belajar terhadap hasil belajar siswa. Teknik pengumpulan data yang digunakan adalah angket, dan dokumentasi. Penelitian ini merupakan penelitian lapangan yang dilaksanakan di suatu Lembaga, yaitu SMA Negeri 1 Tanjung Mutiara Kabupaten Agam.

\section{Hasil dan Pembahasan}

\section{A. Motivasi Belajar Siswa pada Mata Pelajaran Pendidikan Agama Islam di SMA} Negeri 1 Tanjung Mutiara Kabupaten Agam

Motivasi adalah suatu usaha yang didasari untuk mempengaruhi tingkah laku seseorang agar ia tergerak hatinya untuk bertindak melakukan sesuatu sehingga dapat mencapai hasil atau tujuan tertentu (Purwanto, 2007). Belajar merupakan suatu kegiatan yang menimbulkan perubahan tingkah laku dan perubahan tersebut dilakukan melalui kegiatan atau usaha yang disengaja (Sirait, 2016). Dapat dipahami bahwa motivasi belajar menjadi salah satu faktor penting dalam keberhasilan proses belajar yang dilakukan oleh siswa karena dengan adanya motivasi belajar memberikan suatu dorongan untuk menimbulkan perubahan tingkahlaku dan motivasi yang terlihat dari adanya kesungguhan untuk belajar, perasaan senang, perhatian dalam belajar, kerajian belajar, dan kesadaran akan adanya manfaat.

Untuk mengetahui motivasi belajar siswa di SMA Negeri 1 Tanjung Mutiara Kabupaten Agam peneliti menggunakan beberapa indicator motivasi belajar yaitu:

1. Kesungguhan untuk belajar

Kesungguhan dalam belajar menjadi salah satu indikator penting dalam belajar, karena seseorang yang termotivasi dalam belajarnya tentu pasti akan menunjukkan kesungguhannya dalam menuntut ilmu. Berdasarkan penjelasan di atas dapat dipahami bahwa kesungguhan dalam melakukan sesuatu akan menjadi penentu terhadap hasil yang akan diperoleh. Sesuai dengan firman Allah SWT dalam Q.S. Al-Ankabut/29:69:

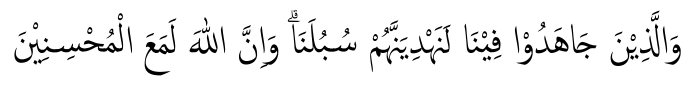

Terjemahan:

"Dan orang-orang yang berjihad untuk (mencari keridhaan) kami, kami akan tunjukkan kepada mereka jalan-jalan kami. Dan sungguh, Allah beserta dengan orang-orang yang berbuat baik."

Dari ayat di atas dapat dipahami bahwa Allah memberi janji kepada orang-orang mukmin, yaitu orang-orang yang berjihad dan bersungguh-sungguh dalam menjalankan ketaatan kepada Allah dan membela agama-Nya yang semata-mata untuk mencari keridhaannya. 
Meli Sopiani dan Wirdati: Pengaruh Motivasi terhadap Hasil Belajar Pendidikan Agama Islam...

2. Perasaan Senang

Perasaan senang merupakan salah satu indikator peserta didik dapat dikatakan memiliki motivasi dalam belajarnya. Jika peserta didik memiliki perasaan senang terhadap suatu mata pelajaran, maka peserta didik tidak akan memiliki rasa terpaksa dalam belajar (Sahdiyah, 2020).

3. Perhatian dalam belajar

Perhatian dalam belajar menjadi salah satu indikator peserta didik yang dapat dikatakan memiliki motivasi dalam belajarnya. perhatian dalam belajar adalah suatu hal yang penting, jika tanpa adanya perhatian dan focus dalam belajar maka informasi dan materi yang disampaikan oleh guru tidak dapat diterima dengan baik dan maksimal oleh siswa.

4. Kerajinan dalam belajar

Seorang yang memiliki motivasi dalam belajar akan terlihat dari kerajinannya dalam belajar karena motivasi menjadi pendorong dalam kerajiannya tersebut.

5. Kesadaran akan adanya manfaat

Seorang peserta didik yang memiliki kesadaran akan manfaat dari suatu pembelajaran akan meingkatkan motivasinya untuk berusaha dengan maksimal agar dapat memperoleh hasil dari apa yang diusahakannya.

Setelah penulis melakukan analisis data terhadap variabel motivasi belajar siswa menggunakan SPSS 24.0, maka untuk mengetahui seberapa pesar motivasi belajar peserta didik di SMA Negeri 1 Tanjung Mutiara Kabupaten Agam dapat dilihat dari hasil analisis skoring dalam bentuk tabel frekuensi nilai rata-rata motivasi belajar siswa sebagai berikut:

Tabel 1. Frekuensi Nilai Rata-Rata Motivasi Belajar Siswa

\begin{tabular}{|c|c|c|c|}
\hline NO & Nilai X & No & Nilai X \\
\hline $\mathbf{1}$ & 142 & $\mathbf{1 8}$ & 121 \\
\hline $\mathbf{2}$ & 123 & $\mathbf{1 9}$ & 93 \\
\hline $\mathbf{3}$ & 133 & $\mathbf{2 0}$ & 112 \\
\hline $\mathbf{4}$ & 134 & $\mathbf{2 1}$ & 124 \\
\hline $\mathbf{5}$ & 124 & $\mathbf{2 2}$ & 122 \\
\hline $\mathbf{6}$ & 134 & $\mathbf{2 3}$ & 113 \\
\hline $\mathbf{7}$ & 136 & $\mathbf{2 4}$ & 127 \\
\hline $\mathbf{8}$ & 139 & $\mathbf{2 5}$ & 134 \\
\hline $\mathbf{9}$ & 138 & $\mathbf{2 6}$ & 126 \\
\hline $\mathbf{1 0}$ & 125 & $\mathbf{2 7}$ & 106 \\
\hline $\mathbf{1 1}$ & 123 & $\mathbf{2 8}$ & 112 \\
\hline $\mathbf{1 2}$ & 135 & $\mathbf{2 9}$ & 114 \\
\hline $\mathbf{1 3}$ & 133 & $\mathbf{3 0}$ & 98 \\
\hline $\mathbf{1 4}$ & 130 & $\mathbf{3 1}$ & 99 \\
\hline $\mathbf{1 5}$ & 136 & $\mathbf{3 2}$ & 125 \\
\hline $\mathbf{1 6}$ & 131 & $\mathbf{3 3}$ & 127 \\
\hline $\mathbf{1 7}$ & 138 & Total & 4107 \\
\hline
\end{tabular}

Berdasarkan tabel di atas diperoleh data sebanyak 33 orang dapat dilihat bahwa skor minimum yang diperoleh dari angket motivasi belajar siswa adalah 93 dan skor maksimumnya yaitu 142. Rata-rata $($ Mean $)=124,45$, median $(M d)=126$, modus $($ Mo $)=$ 134, standar deviasi (SD) $=12,53$. Rentang jumlah skor maksimum (Range) yang dapat diperoleh adalah 142-93 $=49$. Dengan demikian dapat diklasifikasikan kelas interval motivasi belajar sebagai berikut: 
Tabel 2. Kategori Motivasi Belajar

\begin{tabular}{|c|c|c|c|}
\hline$I=16$ & $F$ & $\%$ & $\begin{array}{c}\text { Kategori Motivasi } \\
\text { Belajar }\end{array}$ \\
\hline $\begin{array}{r}126- \\
142\end{array}$ & 17 & $51,5 \%$ & Tinggi \\
\hline $\begin{array}{r}126- \\
142\end{array}$ & 17 & $51,5 \%$ & Tinggi \\
\hline $\begin{array}{c}126- \\
142\end{array}$ & 17 & $51,5 \%$ & Tinggi \\
\hline
\end{tabular}

Berdasarkan tabel di atas dapat disimpulkan bahwa dari 33 siswa yang dijadikan sampel dari angket motivasi belajar, dapat dilihat bahwa terdapat 4 orang siswa antara interval 92-108 sebesar 12,1\% yang berada pada kategori rendah, 12 siswa berada antara interval 109-125 sebesar 36,4\% yang tergolong dalam kategori sedang, dan 17 siswa antara interval 126-142 sebesar 51,5\% yang berada pada kategori tinggi. Dari hasil data tersebuk maka dapat disimpulkan bahwa motivasi belajar siswa pada mata pelajaran Pendidikan Agama Islam di SMA Negeri 1 Tanjung Mutiara tergolong tinggi. Berdasarkan tabel di atas dapat digambarkan pie chart sebagai berikut:

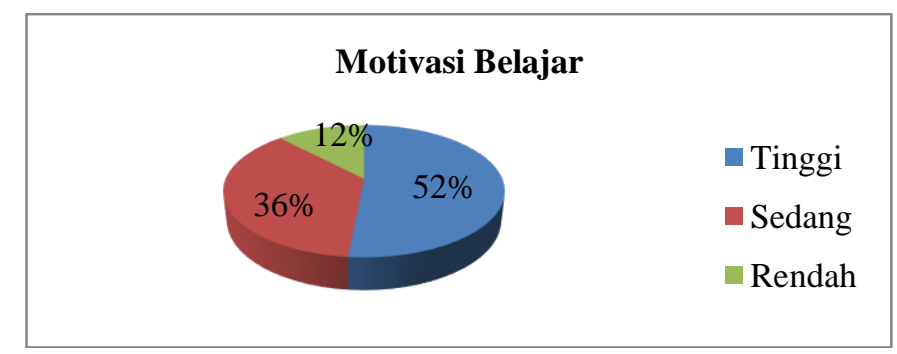

Gambar 1. Pie Chart Motivasi Belajar

\section{B. Hasil Belajar Siswa pada Mata Pelajaran Pendidikan Agama Islam di SMA Negeri 1 Tanjung Mutiara Kabupaten Agam}

Hasil belajar adalah kemampuan nyata yang merupakan hasil interaksi antara faktor yang mempengaruhi baik dari dalam maupun dari luar individu belajar. Menurut (Suryabrata, 2006) hasil belajar adalah evaluasi hasil pembelajaran yang dicapai oleh siswa setelah menjalani proses Pendidikan secara formal dalam jangka waktu tertentu dan hasil belajar tersebut berupa angka-angka.

Dari deskripsi data hasil belajar siswa dalam penelitian ini diperoleh melalui nilai rapor siswa pada mata pelajaran Pendidikan Agama Islam di SMA Negeri 1 Tanjung Mutiara Kabupaten Agam. Adapun data dari nilai rapor siswa dapat dilihat sebagai berikut

\begin{tabular}{|} 
Tabel 3. Data Hasil Belajar Siswa \\
\begin{tabular}{|c|c|c|c|}
\hline No & Nilai & No & Nilai \\
\hline $\mathbf{1}$ & 92 & $\mathbf{1 8}$ & 80 \\
\hline 2 & 80 & $\mathbf{1 9}$ & 77 \\
\hline 3 & 86 & $\mathbf{2 0}$ & 83 \\
\hline $\mathbf{4}$ & 87 & $\mathbf{2 1}$ & 81 \\
\hline $\mathbf{5}$ & 83 & $\mathbf{2 2}$ & 80 \\
\hline 6 & 88 & $\mathbf{2 3}$ & 80 \\
\hline $\mathbf{7}$ & 86 & $\mathbf{2 4}$ & 87 \\
\hline $\mathbf{8}$ & 86 & $\mathbf{2 5}$ & 82 \\
\hline $\mathbf{9}$ & 87 & $\mathbf{2 6}$ & 84 \\
\hline $\mathbf{1 0}$ & 85 & $\mathbf{2 7}$ & 77 \\
\hline $\mathbf{1 1}$ & 84 & $\mathbf{2 8}$ & 82 \\
\hline
\end{tabular}
\end{tabular}


Meli Sopiani dan Wirdati: Pengaruh Motivasi terhadap Hasil Belajar Pendidikan Agama Islam...

\begin{tabular}{|l|l|l|l|}
\hline $\mathbf{1 2}$ & $\mathbf{8 4}$ & $\mathbf{2 9}$ & 86 \\
\hline $\mathbf{1 3}$ & $\mathbf{8 6}$ & $\mathbf{3 0}$ & 77 \\
\hline $\mathbf{1 4}$ & $\mathbf{8 1}$ & $\mathbf{3 1}$ & $\mathbf{7 5}$ \\
\hline $\mathbf{1 5}$ & $\mathbf{8 7}$ & $\mathbf{3 2}$ & 81 \\
\hline $\mathbf{1 6}$ & 82 & $\mathbf{3 3}$ & 81 \\
\hline 17 & $\mathbf{8 4}$ & & \\
\hline
\end{tabular}

Berdasarkan tabel diatas diperoleh data sebanyak 33 orang. dapat dilihat bahwa skor minimum yang diperoleh dari hasil belajar siswa adalah 75 dan skor maksimumnya yaitu 92. Rata-rata $($ Mean $)=83,03$, median $(\mathrm{Md})=83$, $\operatorname{modus}(\mathrm{Mo})=86$, standar deviasi $(\mathrm{SD})=3,7$. Rentang jumlah skor maksimum (range) yang dapat diperoleh adalah 92-75 $=17$. Dengan demikian dapat diklasifikasikan kelas interval dari hasil belajar sebagai berikut:

\begin{tabular}{|c|c|c|c|}
\hline$I=6$ & $F$ & $\%$ & $\begin{array}{c}\text { Kategori Hasil } \\
\text { Belajar PAI }\end{array}$ \\
\hline $87-93$ & 6 & $18,2 \%$ & Tinggi \\
\hline $80-86$ & 23 & $69,7 \%$ & Sedang \\
\hline $73-79$ & 4 & $12,1 \%$ & Rendah \\
\hline
\end{tabular}

Berdasarkan tabel diatas dapat dilihat bahwa hasil belajar siswa pada mata pelajaran Pendidikan Agama Islam di SMA Negeri 1 Tanjung Mutiara terdapat 4 siswa yang berada antara interval $73-79$ sebesar $12,1 \%$ yang tergolong dalam kategori rendah, 23 siswa berada antara interval 80-86 sebesar 69,7\% yang tergolong dalam kategori tinggi, dan 6 orang siswa berada antara interval 87-93 sebesar 18,2\%, yang tergolong dalam kategori sangat tinggi. Jadi dari hasil tersebut dapat disimpulkan bahwa hasil belajar siswa pada mata pelajaran Pendidikan Agama Islam di SMA Negeri 1 Tanjung Mutiara sebagian besar termasuk dalam kategori tinggi. Berdasarkan tabel di atas dapat digambarkan pie chart seperti berikut:

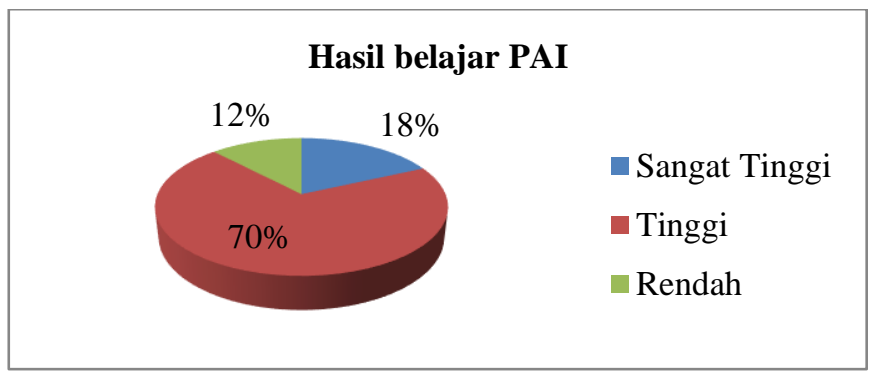

Gambar 2. Pie Chart Hasil Belajar

C. Pengaruh Motivasi Belajar terhadap Hasil Belajar Siswa pada Mata Pelajaran Pendidikan Agama Islam di SMA Negeri 1 Tanjung Mutiara Kabupaten Agam

Peneliti menggunakan uji hipotesis analisis regresi sederhana untuk memperoleh hasil penelitian, analisis ini bertujuan untuk mengetahui pengaruh antara variabel X (motivasi belajar) dengan variabel Y (hasil belajar)

\section{Uji Prasyarat Analisis}

Uji Normalitas

Uji normalitas dilakukan untuk mengetahui apakah populasi data berdistribusi normal atau tidak (Siregar,2013). Salah satu cara untuk mengetahui nilai normalitas adalah dengan rumus Kolmogrov Smirnov yang didapat menggunakan aplikasi dari SPSS for windows 24.0. 


\begin{tabular}{|c|c|c|c|}
\hline \multicolumn{4}{|c|}{$\begin{array}{l}\text { Tabel 5. Hasil Uji Normalitas } \\
\text { Hasil Uji Normalitas One-Sample Kolmogorov- } \\
\text { Smirnov Test }\end{array}$} \\
\hline & $\begin{array}{l}\text { Motivasi } \\
\text { Belajar }\end{array}$ & $\begin{array}{l}\text { Hasil } \\
\text { Belajar }\end{array}$ \\
\hline \multicolumn{2}{|l|}{$\mathrm{N}$} & 33 & 33 \\
\hline \multirow{2}{*}{$\begin{array}{l}\text { Normal } \\
\text { Parametersa }\end{array}$} & Mean & 124.45 & 83.03 \\
\hline & Std. Deviation & 12.530 & 3.746 \\
\hline \multirow{3}{*}{$\begin{array}{l}\text { Most Extreme } \\
\text { Differences }\end{array}$} & Absolute & .151 & .119 \\
\hline & Positive & .093 & .084 \\
\hline & Negative & -.151 & -.119 \\
\hline \multicolumn{2}{|c|}{ Kolmogorov-Smirnov Z } & .866 & .686 \\
\hline \multicolumn{2}{|c|}{ Asymp. Sig. (2-tailed) } & .441 & .735 \\
\hline
\end{tabular}

Berdasarkan hasil uji normalitas pada tabel di atas diperoleh signifikansi 0,441 > 0,05 maka dapat disimpulkan bahwa distribusi variable motivasi belajar adalah normal. Pada analisis kedua diperoleh hasil signifikansi 0,735 $>0,05$ yang berarti menandakan variable hasil belajar adalah normal. Jadi berdasarkan hasil data tersebut dapat disimpulkan nilai signifikansi Kolmogrov-Smirnov (Asymp.Sig) dari kedua variable lebih dari Alpha 0,05 oleh sebab itu dapat dinyatakan bahwa kedua variable berdistribusi normal.

\section{Uji Linearitas}

linearitas bertujuan untuk mengetahui status linear tidaknya suatu distribusi data penelitian (Winarsunu,2006). Pada uji linearitas, dapat dikatakan distribusi data memiliki bentuk yang linear jika nilai signifikansi dari nilai Deviation from linearity sig lebih dari $>0,05$. Sebaliknya jika signifikasi kurang dari $<0,05$ maka data tersebut tidak linear.

\begin{tabular}{|c|c|c|c|c|c|c|c|}
\hline \multicolumn{8}{|c|}{$\begin{array}{c}\text { Tabel 6. Hasil Uji Linearitas } \\
\text { ANOVA Table }\end{array}$} \\
\hline \multirow{6}{*}{$\begin{array}{l}\text { Hasil } \\
\text { Belajar* } \\
\text { Motivasi } \\
\text { Belajar }\end{array}$} & \multirow{4}{*}{$\begin{array}{l}\text { Between } \\
\text { Groups }\end{array}$} & & $\begin{array}{l}\text { Sum of } \\
\text { Squares }\end{array}$ & Df & $\begin{array}{l}\text { Mean } \\
\text { Square }\end{array}$ & $\mathrm{F}$ & Sig. \\
\hline & & (Combined) & 390.303 & 22 & 17.741 & 3.024 & .037 \\
\hline & & Linearity & 275.988 & 1 & $\begin{array}{r}275.98 \\
8\end{array}$ & $\begin{array}{r}47.04 \\
3\end{array}$ & .000 \\
\hline & & $\begin{array}{l}\text { Deviation } \\
\text { from } \\
\text { Linearity }\end{array}$ & 114.315 & 21 & 5.444 & .928 & .580 \\
\hline & \multicolumn{2}{|c|}{ Within Groups } & 58.667 & 10 & 5.867 & & \\
\hline & \multicolumn{2}{|l|}{ Total } & 448.970 & 32 & & & \\
\hline
\end{tabular}

Berdasarkan pada tabel hasil uji linearitas di atas dapat diketahui bahwa nilai signifikasi variabel motivasi belajar (X) terhadap hasil belajar sebesar 0,580 lebih besar dari 0,05, maka dari itu data antara kedua variabel menunjukkan bahwa terdapat hubungan linear yang signifikan antara motivasi belajar $(\mathrm{X})$ dengan hasil belajar (Y

\section{Pengujian Hipotesis \\ Uji Regresi Sederhana}


Meli Sopiani dan Wirdati: Pengaruh Motivasi terhadap Hasil Belajar Pendidikan Agama Islam...

Uji regresi sederhana bertujuan untuk mengetahui pengaruh dari tiap variabel yaitu pengaruh motivasi belajar (X) terhadap hasil belajar siswa (Y) dengan menggunakan persamaan regresi. Untuk menguji besarnya pengaruh motivasi belajar terhadap hasil belajar siswa digunakan analisis regresi sedrhana dengan menggunakan teknik ananlisis statistik yang terdapat dalam program SPSS for windows 24.0. menjawab rumusan masalah "adakah pengaruh positif antara motivasi belajar terhadap hasil belajar siswa pada mata pelajaran Pendidikan Agama Islam di SMA Negeri 1 Tanjung Mutiara" diperoleh data sebagai berikut:

Tabel 7.

\begin{tabular}{|c|c|c|c|c|c|c|}
\hline \multicolumn{7}{|c|}{ ANOVA $^{b}$} \\
\hline \multicolumn{2}{|c|}{ Model } & $\begin{array}{l}\text { Sum of } \\
\text { Squares }\end{array}$ & Df & $\begin{array}{l}\text { Mean } \\
\text { Square }\end{array}$ & & Sig. \\
\hline \multirow[t]{3}{*}{1} & $\begin{array}{l}\text { Regressi } \\
\text { on }\end{array}$ & 275.988 & 1 & 275.988 & $\begin{array}{r}49.46 \\
0\end{array}$ & $.000^{\mathrm{a}}$ \\
\hline & Residual & 172.982 & 31 & 5.580 & & \\
\hline & Total & 448.970 & 32 & & & \\
\hline \multicolumn{4}{|c|}{$\begin{array}{l}\text { a. Predictors: (Constant), Motivasi } \\
\text { Belajar }\end{array}$} & & & \\
\hline \multicolumn{4}{|c|}{ b. Dependent Variable: Hasil Belajar } & & & \\
\hline
\end{tabular}

Bedasarkan hasil tabel di atas diperoleh nilai Fhitung $=49,460$ sedangkan Ftabel $=4,16$ dengan nilai signifikansi $=0,000<0,05(5 \%)$ dengan nilai 49,460 > 4,16. Maka hasil uji regresi sederhana ini dapat diartikan bahwa Ha yang menyatakan motivasi belajar berpengaruh positif terhadap hasil belajar diterima, dan konsekuensi Ho ditolak.

\begin{tabular}{|c|c|c|c|c|c|c|}
\hline \multicolumn{7}{|c|}{$\begin{array}{c}\text { Tabel } 8 . \\
\text { Coefficientsa }\end{array}$} \\
\hline \multirow{2}{*}{\multicolumn{2}{|c|}{ Model }} & \multicolumn{2}{|c|}{$\begin{array}{l}\text { Unstandardized } \\
\text { Coefficients }\end{array}$} & \multirow{2}{*}{$\begin{array}{c}\text { Standardized } \\
\text { Coefficients } \\
\text { Beta }\end{array}$} & \multirow[t]{2}{*}{$\mathrm{T}$} & \multirow[t]{2}{*}{ Sig. } \\
\hline & & B & $\begin{array}{l}\text { Std. } \\
\text { Error }\end{array}$ & & & \\
\hline \multirow[t]{2}{*}{1} & (Constant) & 53.861 & 4.168 & & $\begin{array}{r}12.92 \\
3\end{array}$ & .000 \\
\hline & $\begin{array}{l}\text { Motivasi } \\
\text { Belajar }\end{array}$ & .234 & .033 & .784 & 7.033 & .000 \\
\hline
\end{tabular}

Pada tabel output di atas, diketahui nilai koefisien dari persamaan regresi. Dalam penelitian ini, digunakan persamaan regresi sederhana sebagai berikut:

$\mathrm{Y}=\mathrm{a}+\mathrm{bX}$

Keterangan:

$\mathrm{X}=$ motivasi belajar

$\mathrm{Y}=$ hasil belajar

Dari tabel output hasil persamaan regresi linier sederhana coefficients ${ }^{a}$ diperoleh persamaan regresi berikut:

$\mathrm{Y}=53,861+0,234 \mathrm{X}$ 
Tabel 9. Hasil Koefisien Determinasi

\begin{tabular}{|c|c|c|c|c|c|c|c|c|c|}
\hline \multicolumn{10}{|c|}{ Model Summaryb } \\
\hline \multirow[t]{2}{*}{ Model } & \multirow[t]{2}{*}{$\mathrm{R}$} & \multirow{2}{*}{$\begin{array}{c}\mathrm{R} \\
\text { Square }\end{array}$} & \multirow{2}{*}{$\begin{array}{l}\text { Adjusted } \\
\text { R Square }\end{array}$} & \multirow{2}{*}{$\begin{array}{l}\text { Std. Error } \\
\text { of the } \\
\text { Estimate }\end{array}$} & \multicolumn{5}{|c|}{ Change Statistics } \\
\hline & & & & & $\begin{array}{l}\text { R Square } \\
\text { Change }\end{array}$ & $\begin{array}{c}F \\
\text { Change }\end{array}$ & df1 & df2 & $\begin{array}{l}\text { Sig. F } \\
\text { Change }\end{array}$ \\
\hline 1 & $.784^{\mathrm{a}}$ & .615 & .602 & 2.362 & .615 & 49.460 & 1 & 31 & .000 \\
\hline \multicolumn{10}{|c|}{$\begin{array}{l}\text { a. Predictors: (Constant), Motivasi } \\
\text { Belajar }\end{array}$} \\
\hline \multicolumn{10}{|c|}{$\begin{array}{l}\text { b. Dependent Variable: Hasil } \\
\text { Belajar } \\
\text { S }\end{array}$} \\
\hline \multicolumn{10}{|c|}{$\begin{array}{l}\text { S } \\
\text { arkan tabel hasil uji Determinasi Model Summaryb di atas dapat diketahui bahwa } \\
\text { nilai R square sebesar 0,615 }(61,5 \%) \text {. Hal ini menunjukkan bahwa dengan } \\
\text { menggunakan model regresi, dimana variabel indenpenden (motivasi belajar) } \\
\text { memiliki pengaruh yang kuat terhadap variabel dependen (hasil belajar) sebesar } \\
61,5 \% \text {. Sedangkan } 38,5 \% \text { dipengaruhi oleh faktor lainnya. Dan dari hasil uji } t \text { ini } \\
\text { pula dapat diketahui nilai sign. } 0,000 \text { lebih kecil dari } 0,05(0,000<0,05) \text { ini berarti } \\
\text { terdapat pengaruh yang erat antara motivasi belajar terhadap hasil belajar siswa. }\end{array}$} \\
\hline
\end{tabular}

\section{Uji T}

Dari analisis regresi linear sederhana menggunakan SPSS 24.0 for windows diproleh ounput hasil persamaan regresi linier sederhana coefficients ${ }^{a}$ berikut:

Tabel 10.

\begin{tabular}{|c|c|c|c|c|c|c|}
\hline \multicolumn{7}{|c|}{ Coefficients $^{a}$} \\
\hline \multirow{2}{*}{\multicolumn{2}{|c|}{ Model }} & \multicolumn{2}{|c|}{$\begin{array}{l}\text { Unstandardized } \\
\text { Coefficients }\end{array}$} & \multirow{2}{*}{$\begin{array}{c}\text { Standardized } \\
\text { Coefficients } \\
\text { Beta }\end{array}$} & \multirow[t]{2}{*}{$\mathrm{T}$} & \multirow[t]{2}{*}{ Sig. } \\
\hline & & B & $\begin{array}{l}\text { Std. } \\
\text { Error }\end{array}$ & & & \\
\hline \multirow[t]{2}{*}{1} & (Constant) & 53.861 & 4.168 & & 12.923 & .000 \\
\hline & $\begin{array}{l}\text { Motivasi } \\
\text { Belajar }\end{array}$ & .234 & .033 & .784 & 7.033 & .000 \\
\hline \multicolumn{4}{|c|}{$\begin{array}{l}\text { a. Dependent Variable: Hasil Belajar } \\
\text { Sumber data: data primer diolah } \\
\text { dengan SPSS for windows } 24.0\end{array}$} & & & \\
\hline
\end{tabular}

Dari hasil di atas dapat diambil kesimpulan bahwa $t$ hitung $>t$ tabel yaitu $7,033>1,696$. Karena $t$ hitung $>t$ tabel. Nilai signifikansi $t$ untuk variabel motivasi belajar adalah 0,000 dan nilai tersebut lebih kecil dari probalitas 0,05 $(0,000<$ 0,05). Hal ini berarti menunjukkan Ho ditolak dan Ha diterima. Artinya terdapat pengaruh yang signifikan antara motivasi belajar $(\mathrm{X})$ terhadap hasil belajar siswa (Y).

\section{Simpulan}

Berdasarkan hasil penelitian dan pembahasan yang telah dilakukan peneliti mengenai Pengaruh Motivasi Belajar Terhadap Hasil Belajar Siswa pada Mata Pelajaran Pendidikan Agama Islam di SMA Negeri 1 Tanjung Mutiara Kabupaten Agam, dapat diambil kesimpulan bahwa: 1). Motivasi belajar siswa pada mata pelajaran Pendidikan Agama Islam di SMA Negeri 1 Tanjung Mutiara Kabupaten Agam Tahun Ajaran 2020/2021 tergolong dalam kategori tinggi. Hal ini dapat dibuktikan dari hasil persentase jawaban siswa sebesar $51,5 \%$ atau sebanyak 17 siswa dari 33 responden. 2). Hasil belajar siswa pada mata pelajaran 
Meli Sopiani dan Wirdati: Pengaruh Motivasi terhadap Hasil Belajar Pendidikan Agama Islam...

Pendidikan Agama Islam di SMA Negeri 1 Tanjung Mutiara Kabupaten Agam Tahun Pelajaran 2020/2021 termasuk dalam kategori sedang. Hal ini dapat ditunjukkan dari hasil persentase nilai siswa sebesar $69,7 \%$ atau sebanyak 23 orang siswa dari 33 responden. 3). Terdapat pengaruh yang signifikan antara motivasi belajar terhadap hasil belajar siswa kelas XI MIA pada mata pelajaran Pendidikan Agama Islam di SMA Negeri 1 Tanjung Mutiara Tahun ajaran 2020/2021. Berdasarkan hasil analisis dengan bantuan SPSS for windows 24.0 diperoleh harga koefisien regresi hasil motivasi belajar dari t hitung sebesar 7,033 dan t tabel 1,696 dengan taraf signifikan sebesar 0,05 sehingga dapat disimpulkan $t$ hitung $>$ dari t tabel sehingga terdapat pengaruh yang signifikan antara motivasi belajar terhadap hasil belaajar siswa. Dari uji R square didapatkan nilai R squre sebesar 0,615 (61,5\%) yang menunjukkan bahwa variabel indenpenden (motivasi belajar) memiliki pengaruh yang kuat terhadap variabel dependen (hasil belajar) sebesar 61,5\%. Sedangkan 38,5\% dipengaruhi oleh faktor lainnya. Artinya terdapat pengaruh yang signifikan antara motivasi belajar dengan hasil belajar siswa.

\section{Referensi}

Andriani, R., \& Rasto, R. (2019). Motivasi belajar sebagai determinan hasil belajar siswa. Jurnal Pendidikan Manajemen Perkantoran, 4(1), 80. https://doi.org/10.17509/jpm.v4i1.14958.

Asnawi, S. (2007). Teori Motivasi. Jakarta: Studia Press.

Biatun, N. (2020). Pengaruh motivasi belajar terhadap prestasi belajar PAI di MIN 3 Bantul. Jurnal Pendidikan Madrasah, 5(2), 253-258.

Djamarah, S. B. (2002). Psikologi Belajar. Jakarta: Rineka Cipta.

Haq, A. (2018). Motivasi Belajar Dalam Meraih Prestasi. Jurnal Vicratina, 3, 193-214.

Harmalis. (2019). Motivasi Belajar Dalam Perspektif Islam. Indonesian Journal of Counseling \& Development, 1(1), 56.

Karwono, \& Mularsih, H. (2018). Belajar dan Pembelajaran: Serta Pemanfaatan Sumber Belajar. Depok: Pustaka Belajar.

Mudjiman, H. (2007). Manajemen Pelatihan Berbasis Belajar Mandiri. Yogyakarta: Pustaka Belajar.

Mudjiono, Dimyati. (2006). Belajar dan Pembelajaran. Jakarta: Rineka Cipta.

Munib, A. (2017). Pendekatan Saintifik Dalam Meningkatkan Motivasi Belajar Pendidikan Agama Islam. Al-Ulum: Jurnal Penelitian dan Pemikiran Ke Islaman, 4(2), 243-255. https://doi.org/10.31102/alulum.4.2.2017.243-255.

Rambe, R. N. K. (2018). Penerapan Strategi Index Card Match Untuk Meningkatkan Hasil Belajar Siswa Pada Mata Pelajaran Bahasa Indonesia. Jurnal Tarbiyah, 25(1). https://doi.org/10.30829/tar.v25i1.237

Rusman. (2018). Belajar dan Pembelajaran Berbasis Komputer. Bandung: ALFABETA.

Sardiaman, A.M.(2011). Interaksi dan Motivasi Belajar Mengajar. Jakarta: Raja Grafindo.

Syah, Muhibbin.( 2004). Psikologi Pendidikan Dengan Pendekatan Baru. Bandung: Rosdakarya

Syafaat, A., \& Sahrani, S. (2008). Peranan Pendidikan Agama Islam dalam Mencegah Kenakalan Remaja. Jakarta: Rajawali Press.

Susanto, A. (2013). Teori Belajar dan Pembelajaran di Sekolah Dasar. Jakarta: Prenadamedia Grub

Titin, S. (2016). Pengaruh Metode Pembelajaran Praktik Terhadap Motivasi Dan Hasil Belajar Pendidikan Agama Islam Siswa Kelas IV Sekolah Dasar. Studia Didkatika Jurnal Ilmiah Pendidikan, 10(2), 1-18.

Warti, E. (2018). Pengaruh Motivasi Belajar Siswa terhadap Hasil Belajar Matematika Siswa di SD Angkasa 10 Halim Perdana Kusuma Jakarta Timur. Mosharafa: Jurnal Pendidikan Matematika, 5(2), 177-185. https://doi.org/10.31980/mosharafa.v5i2.273 